\title{
PENERAPAN SISTEM INFORMASI MANAJEMEN PENDIDIKAN DALAM PROSES PEMBELAJARAN DI SMP NEGERI 21 MAKASSAR
}

\author{
LA ODE ISMAIL AHMAD DAN RISTATI SINEN \\ Fakultas Tarbiyah dan Keguruan, UIN Alauddin Makassar \\ J. HM. Yasin Limpo No. 36 Makassar \\ Email: syhila_ismail@yahoo.com
}

\begin{abstract}
:
This study aims to: 1). To know the implementation of management information system in SMP Negeri 21 Makassar. 2). To know the learning process at SMP Negeri 21 Makassar. 3). To know the factors that support the implementation of management information system in SMP Negeri 21 Makassar. This type of research is qualitative, with data acquisition through observation, interview, documentation. The validity of data in this study using triangulation.

The results of this study include: (1). Implementation of Management Information System at SMP Negeri 21 Makassar has been done well. This is manifested in the use of data management applications dapodik and information technology in supporting the learning process by providing educational services based on infrastructure technology, such as learning facilities by combining computers with wifi. (2). Implementation of the learning process in SMP Negeri 21 Makassar is, before implementing the learning process must go through three stages namely, first, the planning stage, by making effective day analysis and analysis of learning programs, making annual programs, preparing syllabus, preparing lesson plans, and make assessment of learning. Second, the implementation phase, by analyzing aspects of the approach, aspects of strategy and tactics, aspects of methods and techniques. Learning media used are, print media (books), pictures, LCD and computer. Third, the evaluation stage of learning knowledge is tested in writing, oral, and a list of exam questions. Evaluation of skills learned evaluated with practice exams, and analysis of tasks evaluated by educators themselves. (3). Factors that support the existence of management information system that is the dapodik system containing data educators and data learners. So it can be concluded that the management information system is very supportive in the world of education, especially in the learning process at SMP Negeri 21 Makassar.
\end{abstract}

Keywords: Information System, Education Management, Learning

\section{PENDAHULUAN}

engelolaan atau manajemen yang baik dalam suatu lembaga pendidikan menjadi hal yang mutlak bagi keberlangsungan hidup lembaga tersebut. Salah satu hal penting yang dapat mempertahankan bahkan mengembangkan sebuah lembaga pendidikan adalah pengelolaan sistem informasi secara tepat (Helmawati, 2015:1). Kemajuan ilmu dan teknologi 
informasi telah banyak mengubah cara pandang dan gaya hidup masyarakat Indonesia dalam menjalankan kegiatannya, termasuk dalam dunia pendidikan.

Peningkatan kinerja pendidikan di masa mendatang diperlukan sistem informasi dan teknologi informasi yang tidak hanya berfungsi sebagai sarana pendukung, tetapi lebih sebagai senjata utama untuk mendukung keberhasilan dunia pendidikan sehingga mampu bersaing di pasar global. Sistem pendidikan telah berusaha untuk melakukan perubahan yang mendasar, misalnya melalui tiga bentuk kebijakan pemerintah. Pertama, meningkatkan ketentuan wajib belajar dari 6 ke 9 tahun. Kedua, mengarahkan pendidikan agar lebih relevan dengan perkembangan industri, dengan teknologi informasi atau memiliki keterkaitan dan kesesuaian. Ketiga, mendorong pendidikan sekolah menengah untuk lebih banyak menyiapkan tenaga terampil sehingga lulusannya tidak memandang perguruan tinggi sebagai satu-satunya alternatif pilihan masa depan (Ety Rochaety, 2006: vii).

Salah satu faktor dalam menciptakan lingkungan belajar dan kondusif dengan lingkungan pandang dan dengar (audio-visual) yang dalam hal ini dapat diciptakan dengan memanfaatkan teknologi informasi. Jadi, dapat diambil kesimpulan bahwasanya untuk mempermudah peserta didik dalam belajar, salah satunya dengan menggunakan media.

Komponen utama yang dibutuhkan untuk menghasilkan sistem informasi manajemen pendidikan yang efektif dan berkualitas, yaitu tersediannya teknologi informasi yang digunakan oleh sumber daya manusia yang mampu mengoperasikannya.

Lingkungan internal maupun eksternal selalu berkembang dan bersifat dinamis sehingga menimbulkan kesempatan atau hambatan pertumbuhan bagi lembaga pendidikan. Penyebabnya adalah keputusan yang dibuat oleh pihak manajemen. Manajemen pendidikan mempunyai tugas membuat keputusan, tetapi tugas ini merupakan aspek krisis yang menuntut kemampuan manajerial untuk mengintegrasikan dan mengembangkan sebagai elemen yang relevan ke dalam situasi lembaga pendidikan secara keseluruhan.

Dalam menjalankan tugasnya pihak manajemen akan dihadapkan pada terbatasnya waktu, resiko yang mungkin mengancam stabilitas lembaga pendidikan dan keputusan yang diambil harus dikomunikasikan pada pihak pelaksana (petugas operasional), seperti pendidik dan tenaga pendidik. Untuk menghadapi hambatan maupun tantangan lingkungan dan kemampuan dalam membuat keputusan, pihak manajemen pendidikan memerlukan strategi yang tepat agar tujuan pendidikan dapat tercapai secara optimal.

Pada umumnya, apabila seseorang membicarakan sistem informasi manajemen, yang tergambar adalah suatu sistem yang diciptakan untuk melaksanakan pengolahan data yang akan dimanfaatkan suatu organisasi. Pemanfaatan di sini dapat berarti penunjang pada tugas-tugas rutin, evaluasi terhadap prestasi organisasi, atau untuk pengambilan keputusan oleh organisasi 
tersebut. Kini kalau seseorang mendengar istilah sistem informasi manajemen, biasa juga mereka membayangkan suatu sistem komputer. Inti pengertian sistem informasi manajemen konvensional tentu saja terkandung dalam pekerjaanpekerjaan sistematis seperti pencatatan agenda, kearsipan, komunikasi di antara manajer-manajer organisasi, penyajian informasi untuk pengambilan keputusan, dan lain sebagainya (Tata Sutabri, 2005: 89).

Berdasarkan observasi awal di SMP Negeri 21 Makassar ditemukan bahwa lembaga pendidikan formal ini mempunyai sistem informasi manajemen, dalam rangka menyikapi segala perubahan dan perkembangan yang terjadi di lingkungannya, khususnya di bidang pendidikan serta perannya dalam proses pembelajaran. Salah satu alasan diterapkan sistem informasi manajemen yaitu untuk memperlancar proses belajar mengajar di sekolah, Karena dilihat dari kondisi peneyediaan bahan ajar atau buku pelajaran sangatlah kurang, maka pendidik di SMP Negeri 21 Makassar memanfaatkan teknologi informasi yang ada untuk mendapat bahan ajar dengan cara mendownload di internet guna memperlancar proses belajar mengajar.

Berdasarkan uraian di atas, penelitian ini akan mengelaborasi beberapa rumusan masalah yakni: 1) Bagaimana penerapan Sistem Informasi Manajemen di SMP Negeri 21 Makassar? 2) Bagaimana Proses Pembelajaran di SMP Negeri 21 Makassar? 3) Faktor-faktor apa yang menghambat dan mendukung tentang penerapan sistem informasi manajemen dalam kelancaran Proses Pembelajaran di SMP Negeri 21 Makassar?

\section{KAJIAN TEORITIK}

\section{Sistem Informasi Manajemen.}

\section{Pengertian Sistem Informasi Manajemen}

Menurut Stoner, sistem informasi manajemen adalah sebuah metode formal untuk menyediakan informasi yang akurat dan tepat waktu bagi manajemen yang diperlukan untuk mempermudah proses pengambilan keputusan, dan memungkinkan fungsi-fungsi dari manajemen seperti perencanaan, pengendalian, dan operasional organisasi dapat dilaksanakan secara efektif. Menurut George M. Scott, sistem informasi manajemen adalah sekumpulan sistem informasi yang saling berinteraksi, yang memberikan informasi baik untuk kepentingan operasi atau kegiatan manajerial (George M. Scott, 1997: 69).

Menurut Ais Zakiyudin dalam bukunya bahwa, sistem informasi manajemen adalah suatu sistem informasi manajemen menggambarkan ketersediaan suatu rangkaian data yang cukup lengkap yang disimpan agar dapat menyediakan informasi untuk mendukung operasi, manajemen, dan pembuatan keputusan dalam suatu organisasi (Ais Zakiyudin, 2011: 15).

Berdasarkan defenisi para ahli, maka dapat disimpulkan bahwa sistem informasi manajemen adalah suatu sistem yang dirancang untuk menyediakan 
informasi guna mendukung pengambilan kepetusan pada kegiatan manajemen dalam suatu organisasi.

Dengan mengacu kepada pengertian sistem informasi manajemen maka dapat disimpulkan bahwa konsep sistem informasi manajemen memiliki beberapa karakteristik yaitu:

a. Dalam suatu organisasi terdapat satu bagian khusus sebagai pengelola sistem informasi manajemen

b. Sistem informasi manajemen merupakan jalinan lalu lintas data dan informasi dari setiap bagian didalam organisasi yang terpusat dibagian sistem informasi manajemen

c. Sistem informasi merupakan jalinan hubungan antar bagian dalam organisasi melalui satu bagian sistem informasi manajemen

d. Sistem informasi manejemen merupakan segenap proses yang mencangkup: pengumpulan data, pengolahan data, penyimpanan data, pengambilan data, dan penyebaran informasi dengan cepat dan tepat.

e. Sistem informasi bertujuan agar para pelaksana dapat melaksanakan tugas dengan baik dan benar serta pimpinan dapat membuat keputusan dengan cepat dan tepat (Suryadi, 2011: 166-167).

Untuk dapat memanfaatkan sistem informasi dengan efektif, maka harus diketahui dengan pasti tentang organisasi, manajemen, dan teknologi organisasi yang membentuk sistem. Berikut ini dijelaskan elemen-elemen sistem informasi manajemen:

Elemen Pertama, yaitu organisasi meliputi manusia, struktur, prosedur operasi, politik, dan kultur. Elemen Kedua, yaitu manajemen, mengamati kesempatan, membuat strategi untuk menjawab kebutuhan, mengalokasikan orang dan sumber dana untuk mendukung strategi yang telah dibuat, mengkoordinasikan pekerjaan atau kegiatan dalam organisasi. Elemen Ketiga, yaitu teknologi informasi yang merupakan alat yang dapat digunakan oleh manajemen untuk membantu melakukan kontrol dan membuat suatu kegiatan baru. Teknologi terdiri atas tiga komponen pokok, yaitu manusia (brainware), perangkat keras (hardware), dan perangkat lunak (software), yang digunakan membantu menerima masukan (input), mengolah, dan mengeluarkan hasil (ourput), serta dapat dipakai untuk meneyebarluaskan hasil olahan atau analisi $(\mathrm{H}$. Afifuddin, 2013: 237).

Tujuan dibentuknya sistem informasi manajemen adalah supaya organisasi memiliki suatu sistem yang dapat diandalkan dalam mengolah data menjadi informasi yang bermanfaat dalam pembuatan keputusan manajemen, baik yang menyangkut keputusan-keputusan rutin maupun keputusan-keputusan strategik. Dengan demikian Sistem Informasi Manajemen adalah suatu sistem yang menyediakan kepada pengelola organisasi data maupun informasi yang berkaitan 
dengan pelaksanaan tugas-tugas organisasi (Wahyudi Kumorotomo dan Subando Agus Margono, 2009: 13).

Maksud dilaksanakannya sistem informasi manajemen pendidikan adalah, sebagai pendukung kegiatan fungsi manajemen dalam rangka menunjang tercapainya sasaran dan fungsi-fungsi operasional dalam organisasi pendidikan.

Dengan adanya sistem informasi manajemen pendidikan, organisasi pendidikan akan merasakan beberapa manfaat sebagai berikut, yaitu: pertama, tersedianya sistem pengelolaan data dan informasi pendidikan. Kedua, terintegrasinya data dan informasi pendidikan untuk mendukung proses pengambilan keputusan. Ketiga tersedianya data dan informasi pendidikan yang lengkap bagi seluruh stakholders yang bergabung dalam bidang pendidikan.

Sistem informasi manajemen pendidikan digunakan oleh penggunanya sebagai alat bantu pengambil keputusan dan oleh pihak yang tergabung dalam interganizational information sistem sehingga organisasi pendidikan dapat berinteraksi dengan pihak berkepentingan (stakeholders). Nilai penting sistem informasi manajemen pendidikan adalah:

1) Sistem informasi yang berbasis komputer memungkinkan pendelegasian kegiatan rutin.

2) Teknologi informasi memungkinkan pengolahan data secara lebih akurat dan andal

3) Pembuatan keputusan akan ditunjang dengan pilihan alternatif yang lebih objektif dengan data pendukung yang lengkap

4) Monitoring dan evaluasi memerlukan penyerapan informasi secara cepat dan efesian.

\section{Bidang Sistem Informasi Manajemen}

Sistem informasi manajemen merupakan suatu badan yang memiliki bagian-bagian yang memiliki tugas-tugas tertentu. Bagian-bagian itu adalah pengumpulan data, penyimpanan data, pemroses data, dan pemrogram data (Made Pidarta, 1998: 157). Dalam bagian-bagian terdapat seseorang coordinator yang bertugas mengkordinir pada semua bagian Dan bertanggung jawab langsung pada manajemen puncak atau kepala sekolah.

a. Bagian Pengumpulan Data

Bertugas mengumpulkan data, baik bersifat internal maupun eksternal. Data internal merupakan data yang berasal dari dalam organisasi (level manajemen), sedangkan data eksternal merupakan data yang berasal dari luar organisasi namun masih terdapat hubungan demean perkembangan organisasi.

Personalia yang bertugas pada pengumpulan data dapat diambilkan dari seluruh unit kerja dalam organisasi yaitu, wakasek sehingga setiap unit kerja 
memiliki wakil-wakil untuk menunjang keefektifan pengumpulan data untuk diolah menjadi sebuah informasi yang bermanfaat bagi pengguna informasi.

b. Bagian Penyimpan Data

Bagian penyimpan data bertugas menyimpan data. Penyimpanan data sangat diperlukan karena tujuan utama adalah demi keamanan data. Apabila levellevel manajemen membutuhkan data, baik berupa data bahan mentah maupun data yang telah diolah, maka data dapat diambil dan digunakan sesuai dengan kebutuhan manajer (kepala sekolah maupun wakilnya).

c. Bagian Pengolah Data

Bagian pengolah data bertugas memproses data dengan mengikuti serangkaian langkah atau pola tertentu sehingga data dirubah ke dalam bentuk informasi yang lebih berguna. Pada pemrosesan data bias dilakukan dilakukan secara manual maupun dengan bantuan mesin. Bagian pemrosesan data terdiri dari beberapa ahli yang bertugas membentuk data menjadi informasi yang sesuai dengan kebutuhan level-level manajemen. Karena kebutuhan setiap manajer (kepala sekolah dan wakil kepala sekolah) berbeda, maka kebutuhan data pada tiap-tiap manajer berbeda pula.

d. Bagian Program Data

Apabila sistem informasi manajemen sudah memiliki perangkat computer, maka bagian pemogram data disebut programmers, yaitu kelompok ahli yang bertanggung jawab atas penyusunan program untuk diberikan kepada perangkat computer. Karena computer memiliki bahasa tersendiri, maka tugas programmer adalah membahasakan data-data yang telah dihimpun sesuai dengan bahasa computer (Sondang P. Siagian, 2006: 159-160).

Badan personalia dalam menjalankan sistem informasi manajemen terdiri dari seorang koodinator yang dipimpin langsung oleh kepala sekolah, pengumpul data (dewan guru) teknisi (programmer). Kesemuanya bertugas sesuai rencana dan posedur pelaksana pada sistem informasi manajemen.

\section{Proses Pembelajaran}

Pembelajaran sebagai perpaduan dari dua aktivitas, yaitu aktivitas mengajar dan aktivitas belajar. Aktivitas mengajar menyangkut peranan seorang pendidik dalam konteks mengupayakan terciptanya jalinan komunikasi harmonis atau interaksi edukatif antara mengajar dengan belajar. Jalinan komunikasi yang harmonis inilah yang menjadi indikator suatu aktivitas/proses pembelajaran itu berjalan dengan baik. Pembelajaran adalah totalitas aktivitas belajar mengajar yang diawali dengan perencanaan diakhiri dengan evaluasi (Salehuddin Yasin, 2010: 65).

Pembelajaran adalah operasionalisasi dari kurikulum. Pembelajaran di sekolah terjadi apabila terdapat interaksi antara siswa dengan lingkungan belajar yang diatur oleh pendidik untuk mencapai tujuan pembelajaran (Nana Sudjana, 
1995: 10). Kaitannya dengan kompetensi sosial pendidik, peserta didik sebagai makhluk sosial dan makhluk etis maka dalam pembelajaran peserta didik diperlakukan secara wajar dan bertujuan agar tercapai optimalisasi potensi pada diri masing-masing peserta didik, memahami dan menerapkan prinsip belajara humanistic yang beranggapan bahwa keberhasilan belajar ditentukan oleh kemampuan yang ada pada diri peserta didik (Hamzah B. Uno, 2009: 19).

Undang-undang tentang Sistem Pendidikan Nasional Nomor 20 Tahun 2003 menyatakan bahwa, pembelajaran adalah proses interaksi peserta didik dengan pendidik dan sumber belajar pada suatu lingkungan belajar. Dalam pembelajaran, pendidik harus memahami hakikat materi pelajaran yang diajarkannya dan memahami berbagai model pembelajaran yang dapat merangsang kemampuan peserta didik untuk belajar dengan perencanaan pengajaran yang matang oleh pendidik.

Berdasarkan defenisi para ahli, dapat disimpulkan bahwa, pembelajaran adalah interaksi peserta didik dengan pendidik dan sumber belajar pada suatu lingkungan belajar yang meliputi pendidik dan peserta didik yang saling bertukar informasi untuk mencapai tujuan pembelajaran.

Pendidik sangat berperan dalam membantu perkembangan peserta didik untuk mewujudkan tujuan hidupnya secara optimal. Keyakinan ini muncul karna tidak semua orang tua memiliki kemampuan baik dari segi pengalaman, pengetahuan maupun ketersediaan waktu. Dalam kondisi yang demikian orang tua menyerahkan anaknya kepada pendidik di sekolah dengan harapan agar anaknya dapat berkembang secara optimal.

Pendidik dalam proses pembelajaran, memiliki peran yang sangat penting. Bagaimanapun hebatnya kemajuan sains dan teknologi, peran pendidik tetap diperlukan. Untuk memenuhi tuntutan peranan pendidik, maka pendidik harus mampu memaknai pembelajaran, serta menjadikan pembelajaran sebagai ajang pembentukan kompetensi dan perbaikan kualitas pribadi peserta didik.

Menurut Mulyasa dalam bukunya Abd. Rahman Getteng, bahwa pendidik harus memacu diri dalam pembelajaran, dengan memberikan kemudahan belajar bagi seluruh peserta didik agar dapat mengembangkan potensinya secara optimal, dan menyenangkan dengan memposisikan diri sebagai berikut: a) Orang tua yang penuh kasih sayang pada peserta didiknya; b) Teman, tempat mengadu, dan tempat mengutarakan perasaan bagi peserta didik; c) Fasilitator yang selalu siap memberikan kemudahan, dan melayani peserta didik sesuai minat, dan pendidik sebagai model; d) Kemampuan dan bakatnya; e) Memberikan sumbangan pemikiran kepada orang tua untuk dapat mengetahui permasalahan yang di hadapi anak dan memberikan saran pemecahannya; f) Memupuk rasa percaya diri, berani dan bertanggung jawab; g) Membiasakan peserta didik untuk saling berhubungan (silaturahmi) dengan orang lain secara wajar; h) Mengembangkan proses sosialisasi 
yang wajar antara peserta didik, orang lain, dan lingkungannya; dan i) Mengembangkan kreativitas

Selain pendidik, unsur lain dalam pembelajaran adalah peserta didik, yakni anggota masyarakat yang berusaha mengembangkan potensi pembelajaran pada jalur pendidikan baik pendidikan informal, pendidikan formal maupun pendidikan nonformal, pada jenjang pendidikan dan jenis pendidikan tertentu.

Para ahli mendefinisikan peserta didik sebagai orang yang terdaftar dan belajar di suatu lembaga pendidikan tertentu, atau peserta didik merupakan orang yang belum dewasa dan memiliki sejumlah potensi yang masih perlu dikembangkan. Sedangkan menurut undang-undang peserta didik adalah anggota masyarakat yang berusaha mengembangkan potensi diri melalui proses pembelajaran yang tersedia pada jalur, jenjang, dan jenis pendidikan tertentu (Undang-Undang Nomor 20 Tahun 2003 Tentang Sistem Pendidikan Nasional).

Dalam proses pendidikan, peserta didik merupakan salah satu komponen manusiawi yang menempati posisi sentral. Peserta didik menjadi pokok persoalan dan tumpuan perhatian dalam semua proses transformasi yang yang disebut pendidikan.

Selain pendidik dan peserta didik, unsur lain dalam pembelajaran adalah sumber belajar yakni semua sarana pengajaran yang menyajikan pesan secara edukatif baik visual saja maupun audiovisual, misalnya buku-buku dan bahan cetak lainnya.

AECT (Association of Education and Communication Tecnology) (1977) mendefinisikan sumber belajar adalah berbagai atau semua sumber baik yang berupa data, orang dan wujud tertentu yang digunakan oleh peserta didik dalam belajar baik secara terpisah maupun terkombinasi sehingga mempermudah peserta didik dalam mencapai tujuan belajar (Sudjarwo, 1989: 141-142). Sumber belajar menurut AECT dibedakan menjadi enam jenis yaitu:

a. Pesan (massage), yaitu informasikan yang di transmisikan atau diteruskan oleh komponen lain dalam bentuk ide, ajaran, fakta, makna, nilai, dan data. Contoh: isi bidang studi yang dicantumkan dalam kurikulum pendidikan formal, dan non formal maupun dalam pendidikan informal.

b. Orang (person), yaitu manusia yang berperan sehingga pencari, penyimpan, pengelolah dan penyaji pesan. Contoh: guru, dosen, tutor, siswa, pemain, pembicara, instruktur dan penatar.

c. Bahan (material), yaitu sesuatu wujud tertentu yang mengandung pesan atau ajaran untuk disajikan dengan menggunakan alat atau bahan itu sendiri tanpa alat penunjang apapun. Bahan ini sering disebut media atau sofware atau perangkat lunak. Buku, modul, majalah, bahan pengajaran terprogram, film, video tape, pita audio (kaset audio), dan sebagainya

d. Alat (device), yaitu suatu perangkat yang digunakan untuk menyampaikan pesan yang tersimpan dalam badan. Alat ini disebut hardware atau perangkat 
keras. Contoh proyektor slide, proyektor film, monitor televisi, monitor komputer, kaset dan lain-lain

e. Teknik (Technique), teknik di artikan sebagai prosedur yang runtut atau acuan yang dipersiapkan untuk menggunakan bahan peralatan, orang dan lingkungan belajar secara kombinasi dan terkoordinasi untuk menyampaikan ajaran atau materi peralatan. Contoh: belajar mandiri, belajar jarak jauh, belajar secara kelompok, simulasi, diskusi, ceramah, problem solving, tanyajawab dan sebagainya.

f. Lingkungan (setting), yaitu situasi disekitar proses belajar mengajar terjadi. Latar atau lingkungan ini dibedakan menjadi dua macam yaitu lingkungan fisik dan non fisik. Lingkungan fisik seperti gedung, sekolah, perpustakaan, laboratorium, rumah, studio, ruang rapat, taman sekolah dan sebagainya. Sedangkan lingkungan non fisik contohnya adalah tatanan ruang belajar, cuaca dan sebagainya.

\section{METODOLOGI PENELITIAN}

Jenis penelitian ini adalah kualitatif, dengan perolehan data melalui observasi, wawancara, dokumentasi. Keabsahan data dalam penelitian ini menggunakan triangulasi.

\section{HASIL PENELITIAN DAN PEMBAHASAN}

\section{Penerapan Sistem Informasi Manajemen di SMP Negeri 21 Makassar}

Sistem informasi manajemen merupakan, bagian dari ilmu manajemen. Semua fungsi manajemen baik itu perencanaan (planning), pengorganisasian (organizing), pemimpin (leading/actuating), dan pengendalian (contrilling) diperlukan untuk keberhasilan kegiatan dalam suatu organisasi, termasuk dalam bidang pendidikan. Keberhasilan saat menjalankan fungsi manajemen tersebut salah satunya ditunjang oleh sistem informasi yang mampu menyediakan informasi yang dibutuhkan para pengolah (pemimpin lembaga tersebut).

Menurut, Marwis Bire selaku Kepala Sekolah menyatakan bahwa:

Sistem informasi manajemen adalah suatu sistem yang berorientasi kepada sistem informasi yang mementingkan keakrutan data dan ketepatan sasaran dalam memperoleh berbagai data dan informasi yang dibutuhkan sekolah. Informasi yang dibutuhkan seperti sarana prasarana, pembiayaan, pengelolaan, kompotensi lulusan, penilaian, standar isi, pendidik dan tenaga kependidikan. Adapun sistem pengelola data yang digunakan disini yaitu DAPODIK yang meliputi data pendidik, tenaga kependidikan, data siswa, data sarana dan prasarana, dan sebagainya yang secara cepat dan valid yang disampaikan kepada instansi seperti Dinas Pendidikan kabupaten/kota, maupun ke kementrian nasional.

Dapodik adalah suatu sistem pendataan dan pengelolaan data-data pendidikan yang bersifat mikro secara online dan real time. Terdapat jenis data 
utama yang dikelola pada sistem dapodik, meliputi data sekolah, data siswa, data pendidik, data karyawan, dan staf sekolah.

Dapodik bertujuan untuk mewujudkan basis data sehingga dapat tercipta tata kelola data pedidikan yang terpadu dan menghasilkan data yang representative untuk memenuhi kebutuhan kementrian dan pemangku kepentingan lainnya. Dan tujuan berikutnya adalah untuk mendukung peningkatan efesiensi, efektif, dan sinergi kegiatan pengumpulan data pokok yang terintegrasi dalam satu sistem pendataan.

Untuk melaksanakan sistem informasi manajemen di SMP Negeri 21 Makassar mempunyai tiga bagian untuk mengolah data yaitu, bagian pengumpulan data, bagian pengolahan data, dan bagian penyimpanan data.

\section{Bagian Pengumpulan Data}

Data yang dikumpulkan berupa data internal dan data eksternal. Data internal merupakan data yang berasal dari dalam organisasi sedangkan data eksternal merupakan data yang berasal dari luar organisasi akan tetapi masi terdapat hubungan dengan perkembangan organisasi.

Data internal dapat diperoleh dari semua unit kerja dalam organisasi yaitu dari wakasek, meliputi wakasek bagian pengajaran, kesiswaan, sarana prasarana, dan humas. Ini berarti bahwa bidang-bidang fungsional dan berbagai satuan kerja dalam organisasi dapat menjadi sumber data. Sedangkan data eksternal dapat diperoleh dari lingkungan sekitar. pengumpulan data secara eksternal harus disesuaikan demean kondisi dan kebutuhan organisasi.

Seperti yang dijelaskan oleh Bapak, Marwis Bire, bahwa:

“Dalam pengumpulan data harus merencanaan data, menetapkan tujuan, jenis data dan waktu pengumpulan data sampai pada pengamanan data. Data dapat diambil dari seluruh unit kerja dalam organisasi yaitu, dari wakasek bagian kesiswaan, pengajaran, sarana dan prasarana, dan keuangan, sehingga disetiap unit yang memiliki waki-wakil akan menunjang keefektifan pengumpulan data untuk diolah menjadi sebuah informasi yang bermanfaat bagi pengguna infomasi. Misalnya bagian kesiswaan meliputi data riwayat siswa, jenis kelamin, latar belakang orang tua dan sebagainya sedangkan bagian pengajaran meliputi pembuatan program tahunan, semester dan perangkat pembelajaran yang akan dilakukan dalam satu semester, bagian keuangan meliputi perencanaan keuangan, pelaksanaan keuangan (penerimaan dan pengeluaran), sedangkan bagian sarana prasarana meliputi pengadaan sarana prasarana, dan mengkoordinasikan pendayagunaan sarana prasarana sekolah."

Dalam hal ini Bapak Firman Suradi menyatakan bahwa:

“Dalam pengumpulan data masih terdapat kesalahan atau kendala yang didapat ketika data yang diinginkan segera dikumpulkan, dari unit kerja terlambat dalam pemberian datanya. Jadi ketika data diinput terkadang kita berungkali mengirimnya." 
Jadi, dapat dikatakan bahwa data dapat diperoleh dari berbagai sumber dalam berbagai bentuk. Pada dasarnya data diperoleh pada fakta-fakta yang ada di lapangan. Data yang memiliki makna tertentu bagi pengembangan organisasi, maka data diklarifikasi dan disusun menjadi informasi.

Pada pengumpulan data dapat dikatakan berjalan baik dan normal apabila semua komponen di sekolah atau seluruh unit kerja tepat waktu dalam pemberian data dan saling bekerja sama untuk mencapai tujuan organisasi.

\section{Bagian Pengolahan Data}

Untuk melakukan pengolahan data tentunya mempunyai prosedur, sebagaimana yang dijelaskan oleh Bapak Marwis Bire, selaku Kepala Sekolah mengatakan:

"Dalam mengolah data dengan mengikuti serangkaian langka tertentu sehingga data diubah ke dalam bentuk informasi yang lebih berguna dengan menggunakan perangkat computer kemudian diinput melalui pengelola data yaitu dapodik. Dengan sistem pengolahan data melalui dapodik maka pengelolaan riwayat data sekolah, peserta didik, pendidik, karyawan sekolah lebih mudah diterintegrasikan dan disimpan secara terpusat dan dapat diakses dengan mudah dalam batasan tertentu melalui internet. Selain itu proses pemutakhiran data dapat dilakukan secara langsung online dan real time dengan memanfaatkan koneksi internet."

Dalam mengolah data dengan prosedur yang telah ditetapkan harus memastikan prosedur tersebut telah terbebas dari kesalahan meliputi:

a. Koneksi peralatan pendukung untuk mengecek pendeteksian kode

b. Memastikan bahwa prosesor yang digunakan tidak terdapat kesalahan

c. Pengecekan terhadap kompatibilitas program sebelumnya dengan program baru yang digunakan

d. Ketersediaan prosedur.

Untuk melakukan pencegahan kesalahan yang terjadi sehingga perlu disediakan prosedur pencegahan yang memberikan informasi tentang prosedur yang benar kepada operator dalam pengolahan data. Dalam hal ini, Muh Firman Suradi mengatakan bahwa:

“Dalam mengolah data juga harus dilakukan secara berkesenambungan karena dengan perkembangan waktu maka secara otomatis juga akan mengalami perubahan pada data untuk mengantisipasi perubahan data pada unit pengolah data harus selalu meng-up date data sesuai dengan kenyataan."

Seiring dengan perkembangan waktu, secara otomatis fakta yang terjadi juga mengalami perkembangan. Hal ini berpengaruh pada data-data yang diperlukan. Untuk mengantisipasi perubahan data yang terjadi setiap waktu, unit pengolah data harus mengikuti dan meng-up date data sesuai dengan kenyataan, karena hal ini 
akan mempengaruhi informasi yang diterima manajer (kepala sekolah dan wakilwakilnya) dan akan berdampak besar pada perkembangan organisasi.

Dengan demikian dapat disimpulkan bahwa pengolahan data dilakukan secara langsung online dan real time dengan memanfaatkan koneksi internet dan pengolahan data harus dilakukan secara terus menerus dan berkesenambungan di mana unit pengolah data harus mengikuti dan meng-up date data sesuai dengan kenyataan karena hal ini akan mempengaruhi informasi yang diterima manajer (kepala sekolah dan wakil-wakilnya) dan akan berdampak besar pada perkembangan organisasi.

\section{Bagian Penyimpanan Data}

Penyimpana data sangat diperlukan, karena tujuan utamanya adalah demi keamanan data. Apabila level-level manajemen membutuhkan data, baik data berupa bahan mentah maupun data yang telah diolah, maka data dapat diambil dan digunakan sesuai dengan kebutuhan manajer (kepala sekolah dan wakilwakilnya). Penyimpanan informasi sangat penting karena tidak semua informasi yang dimiliki digunakan saat sekarang tetapi sesuai dengan kebutuhan. Menurut Marwis Bire bahwa:

“Untuk menjaga validitas data sekolah, siswa, pendidik dan karyawan, pada sistem dapodik maka diterapkan sistem penomoran khusus yang berfungsi sebagai identitas tunggal yang berlaku seumur hidup dalam skala nasional. Sistem penomoran tersebut menjadi kunci utama Dan demi keamanan data dari sistem dapodik. Maka terdapat tiga subprogram pada dapodik yaitu, NPSN (Nomor Pokok Sekolah Nasional), NISN (Nomor Induk Siswa Nasional), dan NIGN (Nomor Induk Nasional)."

Nomor induk siswa nasional (NISN) adalah kode pengenal siswa yang bersifat tunggal dan berlaku seumur hidup membedaka satu siswa dengan siswa lainnya. Penerapan kode pengenal siswa disetiap sekolah pada sistem dapodik dapat terjaga validitasnya.

Nomor pokok sekolah nasional (NPSN) merupakan kode pengenal sekolah yang bersifat tunggal dan berlaku selama sekolah tersebut aktif. Kode terbaru ini disiapkan untuk menggantikan (NSS-Nomor Statistik Sekolah) yang dinilai sudah konsisten dan sangat rentang terhadap perubahan wilayah/daerah Indonesia. NPSN seluruh angka demean jumlah 10 digit sehingga mudah dihafal atau dituliskan.

Nomor Induk Guru Nasional (NIGN) adalah kode pengenal guru/karyawan yang berlaku seumur hidup. Penerapan kode pengenal guru/karyawan yang berlaku secara nasional, maka data guru/karyawan pada sistem dapodik terjaga validitasnya.

Pada implementasinya, melalui pengolah data dapodik, sekolah diberikan tanggung jawab dalam mengumpulkan data siswa, sekolah, dan guru/karyawan 
dan mengoperasikan sistem dapodik yang telah disediakan dan melaporkan hasil kerja masing-masing.

Untuk menjaga keberlanjutan data siswa, sekolah, guru, dan karyawan yang valid pada dapodik maka perlu dioptimalkan penggunaan NISN, NPSN dan NIGN sebagai salah satu syarat utama dalam pelaksanaan program kegiatan di depdiknas, meliputi: Bantuan Operasional Sekolah (BOS), Nomor Ujian di sekolah atau tingkat nasional, statistik pendidikan, dan sertifikat guru. Dalam hal ini Muh. Firman Suradi menyatakan bahwa:

"Kegiatan penyimpanan informasi sangat penting agar terjamin keamanannya, hemat biaya, serta mudah dicari dan diambil apabila diperlukan sewaktu-waktu. Selain dalam ingatan manusia, penyimpanan informasi dapat dilakukan pada alat-alat seperti hardisk, flashdisk, dan sebagainya."

Jadi, dapat disimpulkan bahwa informasi yang telah terkumpul dan terolah dengan baik perlu disimpan dengan sebaik mungkin mengingat informasi sebagai salah satu sumber daya strategis dalam organisasi, maka penerapan kode dilakukan agar terjaga validitas data tersebut.

Untuk menjalankan suatu organisasi, tentu diberikan amanah dan tanggung jawab kepada seseorang agar suatu organisasi berjalan sesuai dengan tahapantahapan yang sudah direncanakan sebelumnya. Dalam hal ini menurut Muh. Firman Suradi menyatakan bahwa:

"Yang bertindak sebagai pelaksana sistem informasi manajemen adalah wakil kepala sekolah yang terdiri dari empat personil seperti Wakasek bagian pengajaran, kesiswaan, sarana dan prasarana, dan humas. Hal yang dibagi misalnya dari kesiswaan yaitu dari seluruh siswa diinput datanya mulai dari data riwayat pendidikan, status keluarga kemudian semua itu dimasukkan dalam sebuah sistem dapodik yang dikoordinir oleh operator sekolah."

Jadi dapat disimpulkan bahwa yang bertindak sebagai ketua sistem informasi manajemen adalah kepala sekolah sekaligus penaggung jawab, Dan yang bertindak sebagai pelaksana sistem informasi manajemen adalah wakil kepala sekolah yang terdiri dari empat personil seperti wakasek bagian pengajaran, kesiswaan, sarana prasarana dan humas.

Dalam dunia pendidikan penggunaan dan pengelolaan sistem informasi manajemen pendidikan tidak dapat dipisahkan dari aktivitas pendidikan itu sendiri. Kedua bidang ini saling membutuhkan karena manajemen menilai pendidikan sebagai penggerak pada sistem informasi manajemen pendidikan sekaligus sistem informasi pendidikan sebagai penentu proses manajemen pendidikan.

Hal ini terjadi di SMP Negeri 21 Makassar bahwa, sistem informasi manajemen sangat berperan dalam dunia pendidikan khususnya dalam proses belajar mengajar di SMP Negeri 21 Makassar. Sebagaimana yang di jelaskan oleh Bapak Muh. Firman Suradi, selaku Kepala Tata Usaha. Berikut penjelasannya: 
“Dengan diterapkan sistem informasi manajemen disekolah, dapat dijadikan sebagai salah satu dasar dalam meningkatkan mutu pendidikan dimana dalam memberikan kesempatan kepada guru dan pengurus sekolah untuk meningkatkan kualitas komunikasi dan pembinaan kepada siswa. Siswa juga lebih mengembangkan kepribadian dan pengetahuannya. Misalnya penggunaan teknologi dengan memfasilitasi praktek pembelajaran dengan memadukan computer dengan penggunaan wifi atau jaringan internet. Jadi, ketika dalam proses belajar mengajar akan menciptakan suasana yang efektif, mereka dapat dengn mudah mengerjakan tugas, dalam proses belajar mengajar tidak membosankan, siswa lebih aktif dan semangat belajarnya."

Berdasarkan semua pernyataan informan di atas, maka peneliti dapat menarik kesimpulan bahwa penerapan sistem informasi manajemen pada lembaga pendidikan sangat dibutuhkan, karena dalam menghadapi persaingan global lembaga pendidikan dituntut untuk memberikan informasi lebih cepat, akurat dan nyaman yang merupakan bagian dari kualitas pelayanan, sehingga akan menjadi keunggulan bersaing.

\section{Pelaksanaan Proses Pembelajaran di SMP Negeri 21 Makassar}

Berikut peneliti memberikan penjelasan mengenai pelaksanaan proses pembelajaran di SMP Negeri 21 Makassar. Tapi sebelum kita membahas lebih lanjut mengenai pelaksanaan proses pembelajaran di SMP Negeri 21 Makassar berikut sedikit penjelasan mengenai proses pembelajaran.

Proses pembelajaran merupakan proses interaksi peserta didik dengan pendidik dan sumber belajar pada suatu lingkungan belajar yang meliputi pendidik dan peserta didik yang saling bertukar informasi.

Pendidik sangat berperan dalam membantu perkembangan peserta didik untuk mewujudkan tujuan hidupnya secara optimal.

Pendidik dalam proses pembelajaran memiliki peran yang sangat penting bagaimana pun hebatnya kemajuan sains dan teknologi, peran pendidik tetap diperlukan.

Untuk melaksanakana proses pembelajaran, mempunyai tiga tahapan dalam proses pembelajaran yaitu: tahapa perencanaan, tahap pelaksana, dan tahap evaluasi.

\section{Tahap Perencanaan}

Kegiatan perencanaan yang baik senantiasa berawal dari rencana yang matang. Perencanaan yang matang menunjukkan hasil yang optimal dalam pembelajaran. Perencanaan merupakan proses penyusunan sesuatu yang dilaksanakan untuk mencapai tujuan yang telah ditentukan.

Dalam hal ini sebelum melaksanakan proses pembelajaran di SMP Negeri 21 Makassar, terlebih dahulu harus mempunyai perencanaan/persiapan. Sebagaimana yang telah dijelaskan oleh Bapak Hasanuddin selaku Wakasek Bidang Kurikulum dalam wawancaranya mengatakan bahwa: 
"Sebelum melaksanakan proses pembelajaran harus mempunyai kesiapan yaitu: pertama, Analisis hari efektif dan analisis program pembelajaran. Untuk mengawali kegiatan penyusunan program pembelajaran, guru perlu membuat analisis hari efektif selama selama satu semester. Dari hasil analisis hari efektif diketahui jumlah hari efektif dan hari libur tiap pekan atau tiap bulan sehingga memudahkan penyusunan program pembelajaran selama satu semester. Dasar pembuatan analisis hari efektif adalah kalender pendidikan dan kalender umum. Berdasarkan analisis hari efektif tersebut dapat disusun analisis program pembelajaran. Kedua, membuat program tahunan, dan program semester. Yang dimaksud dengan program tahunan yaitu, penyusunan program pembelajaran selama tahun pelajaran dimaksudkan agar keutuhan dan kesinambungan program pembelajaran atau topik pembelajaran yang dilaksanakan dalam dua semester tetap terjaga. Program semester yaitu, penyusunan program semester didasarkan pada hasil analisis hari efektif dan program pembelajaran tahunan. Ketiga, Menyusun Silabus. Yang dimaksud dengn silabus yaitu, penjabaran dari standar kompetensi, kompetensi dasar yang ingin dicapai, dan pokok-pokok serta uraian materi yang perlu dipelajari siswa dalam rangka mencapai standar kompetensi dan kompetensi dasar. Keempat, Menyusun Rencana Proses Pembelajaran (RPP). RPP disusun guru sebelum melakukan proses pembelajaran. RPP bersifat khusus dan kondisional, dimana setiap sekolah tidak sama kondisi siswa dan sarana prasarana sumber belajarnya. Karena itu, penyusunan RPP didasarkan pada silabus dan kondisi pembelajaran agar kegiatan pembelajaran dapat berlangsung sesuai harapan. Kelima, Penilaian Pembelajaran. Yang dimaksud penilaian pembelajaran yaitu, proses yang harus dilakukan guru dalam rangkaian kegiatan pembelajaran. Prinsip penilaian antara lain valid, mendidik berorientasi pada kompetensi, adil, objektif, terbuka, dan berkesenambungan."

Dalam hal ini dijelaskan pula oleh Ibu Nurbaya bahwa:

"Sebelum melakukan pembelajaran, pendidik terlebih dahulu menyampaikan tujuan dan indikator-indikator yang akan dicapai pada setiap pertemuan pembelajaran, dengan menggunakan teknologi informasi dan media pembelajaran yaitu berupa computer dan LCD."

Jadi, dapat disimpulkan bahwa, sebelum melaksanakan proses pembelajaran terlebih dahulu menyiapkan segala sesuatu yang diperlukan dalam proses pembelajaran seperti, menganalisi hari efektif dan analisis program pembelajaran, membuat program tahunan dan program semester, menyusun silabus, menyusun RPP, dan membuat penilaian pembelajaran. Kemudian sebelum menyampaikan materi/informasi terlebih dahulu menyampaikan tujuan pembelajan dan indikatorindikator pembelajaran yang akan dicapai.

\section{Tahap Pelaksanaan}

Tahap ini merupakan tahap implementasi atau tahap perencanaan atas desain perencanaan yang telah dibuat guru. Dalam tahap ini, guru melakukan interaksi belajar mengajar melalui penerapan berbagai strategi metode dan teknik pembelajaran, serta pemanfaatan seperangkat media. 
Seperti yang dijelaskan oleh Bapak Hasanuddin bahwa:

“Dalam tahap pelaksanaan pembelajaran ada beberapa hal yang perlu diperhatikan guru yaitu, pertama, Aspek Pendekatan dalam Pembelajaran. Pendekatan ini berupa pendekatan pembelajaran pemrosesan informasi, yaitu membantu siswa untuk memproses informasi yang diperoleh pendekatan pembelajaran individu yaitu, membantu siswa mengembangkan pribadi agar lebih produktif terhadap situasi dan lingkungan. Kedua, Aspek Strategi dan Taktik dalam Pembelajaran. Strategi pembelajaran yaitu, tindakan pembelajaran yang dilakukan guru yang dinilai strategis untuk mengaktualisasikan proses pembelajaran. Terkait dengan pelaksanaan strategi adalah taktik pembelajaran. Taktik pembelajaran berhungan dengan tindakan teknis untuk menjalankan strategi. Untuk melaksanakan strategi diperlukan kiat-kiat teknis, agar nilai strategis setiap aktivitas yang dilakukan guru, murid di kelas dapat terealissi. Ketiga, Aspek Metode dan Teknik dalam Pembelajaran. Metode merupakan bagian dari sejumlah tindakan strategis yang menyangkut tentang cara, bagaimana interaksi pembelajaran dilakukan. Metode yang digunakan dalam proses pembelajaran yaitu, metode ceramah, berdiskusi, bekerja kelompok, bersimulasi, dan sebagainya. Dan media pembelajaran yang digunakan yaitu, media cetak (buku), gambar, LCD dan komputer."

Hal ini pula dijelaskan oleh Ibu Ratnawati bahwa:

"Untuk mengembangkan potensi peserta didik, peserta didik membuat kelompok belajar yang diarahkan langsung oleh guru mata pelajaran dengan menggunakan media pembelajaran berupa computer dan LCD, peserta didik mencari materi yang mereka butuhkan kemudian mendiskusikannya atau memecahkan masalah yang tidak dipahami dengan teman kelompok lainnya."

Pendidik juga harus mampu memahami dan memberikan solusi atas segala kesulitan yang dihadapi peserta didik dalam proses pembelajaran. Untuk itu pendidik dituntut untuk mengenal peserta didiknya, sebagaimana yang dijelaskan oleh Ibu Nurbaya bahwa:

“Apabila peserta didik mendapat kesulitan dalam pembelajara, maka guru mata pelajaran membimbing peserta didik dengan menggunakan media pembelajaran untuk memaparkan pelajaran dan mempraktekkan agar dengan mudah peserta didik memahami apa yang dijelasksen pendidik."

Jadi dapat disimpulkan bahwa dalam tahap pelaksanaan proses pembelajaran yaitu, menggunakan aspek pendekatan, menggunakan aspek strategi dan taktik dalam proses pembelajaran, menggunakan metode dan teknik dalam proses pembelajaran. Metode yang digunakan dalam proses pembelajaran yaitu, ceramah, berdiskusi, berkelompok, bersimulasi, dan sebagainya. Media yang digunakan dalam proses pembelajaran yaitu, media cetak (buku), gambar, LCD, dan komputer. 


\section{Tahap Evaluasi}

Pada tahap evaluasi, kegiatan guru adalah melakukan penilaian atas proses pembelajaran yang telah dilakukan. Evaluasi adalah alat untuk mengukur ketercapaian tujuan. Dengan evaluasi, dapat diukur kuantitas dan kualitas pencapaian tujuan pembelajaran. Dalam hal ini dijelaskan oleh Bapak Hasanuddin, bahwa:

“Evaluasi pengetahuan belajar dapat dilakukan dengan ujian tulis, lisan, dan daftar ujian pertanyaan. Evaluasi belajar keterampilan, dapat dilakukan dengan ujian praktek, analisis keterampilan dan analisis tugas serta evaluasi oleh peserta didik sendiri. Evaluasi belajar sikap dapat dilakukan dengan daftar sikap isian, daftar isian sikap yang disesuaikan dengan tujuan program, dan skala deferensial sematik."

Dijelaskan pula oleh Ibu Ratnawati bahwa:

“Apapun bentuk tes yang diberikan kepada peserta didik, tetap harus sesuai dengan persyaratan yang baku, yakni tes itu harus: Memeiliki Validitas yaitu, mengukur atau menilai apa yang hendak diukur atau dinilai, terutama menyangkut kompetensi dasar dan materi standar yang telah dikaji. Mempunyai reliabilitas yaitu, ketetapan hasil yang diperoleh peserta didik, bila dites kembali dengan tes yang sama. Pelaksanaan evaluasi harus efesien dan praktis."

Jadi dapat disimpulkan bahwa dalam melaksanakan tahap evaluasi, yang perlu dievaluasi oleh pendidik yaitu, pengetahuan belajar yang dites dengan secara tertulis, lisan, dan daftar pertanyaan ujian. Evaluasi belajar keterampilan yang dievaluasi dengan ujian praktek, dan analisis tugas yang dievaluasi sendiri oleh pendidik. Dan bentuk tes yang diberikan kepada peserta didik tetap harus dengan persyaratan yang baku.

Keberadaan teknologi informasi sangat membantu dalam pelaksanaan proses belajar mengajar. Mempermudah pendidik dalam menyampaikan informasi, dan mempermudah dalam mencari bahan ajar. Sebagaimana dijelaskan oleh Ibu Ratnawati bahwa:

“Teknologi informasi sangat mendukung dalam proses belajar mengajar, karena membantu pendidik menyampaikan informasi dengan menggunakan media pembelajaran seperti LCD dan komputer, teknologi informasi juga membantu pendidik dan peserta didik dalam mencari bahan ajar untuk memperlancar proses belajar mengajar."

Jadi, dapat disimpulkan bahwa, pelaksanaan proses pembelajaran adalah interaksi peserta didik dengan pendidik dan sumber belajar pada suatu lingkungan belajar yang meliputi pendidik dan peserta didik yang saling bertukar informasi yang menggunakan media pembelajaran berupa, media cetak (buku), gambar, LCD, computer, dan sebagainya. Dan memanfaatkan teknologi informasi untuk menyampaikan informasi dan mencari bahan ajar untuk memperlancar proses pembelajaran. 
Faktor Yang Menghambat Dan Mendukung Penerapan Sistem Informasi Manajemen Dalam Proses Pembelajaran Di SMP Negeri 21 Makassar.

Dalam penerapan sistem informasi manajemen di SMP Negeri 21 Makassar ada beberapa factor yang menghambat dan mendukung dengan adanya sistem informasi manajemen. Sebagaimana yang dijelaskan oleh Bapak, Muh. Firman Suradi, selaku Kepala Tata Usaha dalam petikan wawancara berikut ini:

"Faktor yang menunjang sistem informasi manajemen yaitu, dengan adanya sistem dapodik yang melakukan pendataan tentang data pendidik, peserta didik, dan karyawan. Kemudian factor yang menghambat sistem informasi manajemen yaitu, kesalahan dan keterlambatan pemberian data dari tiap-tiap unit kerja".

Jadi, dapat disimpulkan bahwa factor yang menunjang Dan menghambat penerapan sistem informasi manajemen di SMP Negeri 21 Makassar yaitu, dengan adanya sistem dapodik dan adanya kesalahan Dan keterlambatan pemberian data dari tiap-tiap unit kerja.

\section{KESIMPULAN DAN SARAN}

Berdasarkan data-data yang dikumpulkan dan dijelaskan pada bagian sebelumnya peneliti dapat memperoleh kesimpulan sebagai berikut:

1. Penerapan sistem informasi manajemen sangat penting dilembaga pendidikan khusunya di SMP Negeri 21 Makassar. Di mana menggunakan aplikasi pengolah data yaitu dapodik dan teknologi informasi dalam mendukug proses pembelajaran memberikan layanan pendidikan dengan menfasilitasi praktek pembelajaran dengan menggunakan infrakstruktur teknologi, seperti fasilitas belajar dengan memadukan computer.

2. Pelaksanaan proses pembelajaran di SMP Negeri 21 Makassar berdasarkan hasil penelitian yaitu, sebelum melaksanakan proses pembelajaran harus melalui tiga tahap yaitu, pertama, tahap perencanaan. Dalam tahap ini membuat analisis hari efektif dan analisis program pembelajaran, membuat program tahunan, menyusun silabus, menyusun RPP, dan membuat penilaian pembelajaran. Kedua, tahap pelaksanaan. Dalam tahap ini yang perlu dilakukan yaitu, Aspek pendekatan dalam pembelajaran, Aspek stretegi dan taktik dalam pembelajaran, Aspek metode dan teknik dalam pembelajaran. Media pembelajaran yang dipakai dalam proses pembelajaran yaitu, media cetak (buku), gambar, LCD dan computer. Ketiga, tahap evaluasi. Dalam tahap ini yang dievaluasi yaitu, pengetahuan belajar yang dites dengan secara tertulis, lisan, dan daftar pertanyaan ujian. Evaluasi belajar keterampilan yang dievaluasi dengan ujian praktek, dan analisis tugas yang dievaluasi sendiri oleh pendidik. Dan bentuk tes yang diberikan kepada peserta didik tetap harus dengan persyaratan yang baku. 
Adapun saran-saran yang dapat diberikan sehubungan dengan hasil penelitian ini adalah sebagai berikut:

1. Disarankan dalam pelaksanaan sistem informasi manajemen agar lebih dikembangkan lagi.

2. Disarankan dalam pelaksaan proses pembelajaran pendidik lebih sering menggunakan teknologi informasi agar proses belajar mengajar berjalan dengan baik.

\section{DAFTAR PUSTAKA}

Afifuddin H. Dasar-Dasar Manajemen, Bandung: Alfabeta, 2013

DEPAG RI, Al-Qur'an dan Terjemahan, Bandung: Jumanatul Ali, 2004.

Getteng ABD Rahman, Menuju Guru Profesional dan Ber-Etika, Yogyakarta: Rrha 2014.

Geoege M. Scott, Prinsip-Prinsip Sistem Informasi Manajemen, Jakarta: PT Rajagafindo Persada, 1997.

Helmawati. Sistem Informasi Manajemen, Bandung: PT Remaja Rosdakarya Offset, 2015

Hamalik Oemar. Kurikulum dan pembelajaran. Jakarta:Bumi Aksara, 2005

Isbani, Media Pendidikan, Surakarta: UNS Press, 1987.

Kumurotomo Wahyudi, Sistem Informasi Manajemen, Yogyakarta: Gaja Mada University Press, 2009

Moleng J. Lexy, Metode Penelitian Kualitatif, Bandung: Remadja Rosdakarya, 1999

Rochaety Eti, Sistem Informasi Manajemen, Jakarta: Mitra Wacana Media, 2011

Sudjarwo, Beberapa Aspek Pengembangan Sumber Belajar, Jakarta: PT Mediatama Sarana Perkasa, 1989.

Soeharto Karti, Teknologi Pembelajaran Pendekatan Sistem, Konsepsi dan odel SAP, Evaluasi Sumber Belajar dan Media, Surabaya: SIC 2003.

Siswanto H. B. Pengantar Manajemen, Jakarta: Bumi Aksara 2011

Sudjana Nana, Teknologi Pengajaran, Bandung: Sinar Baru, 1989

Subagyo Joko, Metode Penelitian dalam teori dan praktek Jakarta: Rineka Cipta, 1991

Sutabri Tata, sistem informasi manajemen. Yogyakarta: Andi, 2005

Sugiyono, Metode Penelitian Pendidikan; pendekatan kuantitaf, kualitatif. Bandung: Alfabet 2014

Sugiyono, Metode Penelitian Pendidikan; Pendekatan Kuantitatif, Kualitatif dan R \& D. Cet. VI, Bandung: Alfabeta, 2008

Surahmad Winarno, Pengantar Penelitian IImiah Metode dan Teknik, Bandung: Tarsito 2008 
Tirtaraharja Umar dan Lasula, Pengantar Pendidikan, Jakarta: Rineka Cipta, 2000. Undang-undang No.20 tentang sisdiknas Jakarta: Sinar Grafindo, 2003 Uno B. Hamzah, Perencanaan Pembelajaran. Jakarta: PT Bumi Aksara, 2009 Prima Gusti Yanti Ponjorini Rahayuningsi, Ety Rochaety. Sistem Informasi Manajemen Pendidikan, Jakarta: Bumi Aksara, 2006

Yasin Salehuddin, pengelolaan Pembelajaran, Makassar: Alauddin Press 2010 Zakiyudin Ais. Sistem Informasi Manajemen. Jakarta: Mitra Wacana Media 2011 